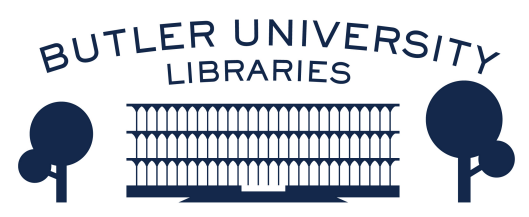

Journal of Hindu-Christian Studies

January 2007

\title{
Book Review: "Magical Progeny, Model Technology: A Hindu Bioethics of Assisted Reproductive Technology"
}

Harold Coward

Follow this and additional works at: https://digitalcommons.butler.edu/jhcs

Part of the Religion Commons

\section{Recommended Citation}

Coward, Harold (2007) "Book Review: "Magical Progeny, Model Technology: A Hindu Bioethics of Assisted Reproductive Technology"," Journal of Hindu-Christian Studies: Vol. 20, Article 17.

Available at: https://doi.org/10.7825/2164-6279.1392

The Journal of Hindu-Christian Studies is a publication of the Society for Hindu-Christian Studies. The digital version is made available by Digital Commons @ Butler University. For questions about the Journal or the Society, please contact cbauman@butler.edu. For more information about Digital Commons @ Butler University, please contact digitalscholarship@butler.edu. 


\section{BOOK REVIEWS}

\section{Magical Progeny, Model Technology: A Hindu Bioethics of Assisted Reproductive Technology. Swasti Bhattacharyya. Albany: State University of New York Press, 2006, 163 pp.}

HOW does Hindu Ethics approach the complex issues involved in the modern medical practice of "Assisted Reproductive Technology" (including sperm donation, in vitro-fertilization and surrogacy)? The author is well placed to write on this question, having trained as a nurse and worked in clinical settings as well as completing a Ph.D. in Hindu Bioethics focused on this question. In her book Swasti Bhattacharyya offers a wide blend of theory and practice as she sets out to examine how key elements of Hindu thought can deal with the complex issues involved in infertility and reproductive technology. Differences with Western perspectives are highlighted throughout by engaging in cross-cultural comparisons with Western bioethics (assumed in modern medicine) and Roman Catholic thought and practice. Her approach is interdisciplinary in that she draws together evidence from nursing, bioethics, Hindu culture and religion along with contemporary voices from a Hindu community in California and a case study. Thematic unity is provided by grounding the analysis on creative insights drawn from the Hindu epic, the Mahabharata, and the way it deals with challenges of infertility. This gives the book an appropriate focus on women's experience throughout.

Chapter 1 explores the importance of religion within the practice of medicine and the application of bioethics, and argues that for those working within the medical field to be good clinicians it is imperative "to be informed of, and sensitive to their own religious and cultural perspectives as well as those of their patients." (p. 5). At the same time assumptions and stereotypes must be guarded against. Chapter 2 presents a synopsis of the Mahabharata and the stories of how the three queens Kunti, Madri and Gandhari overcome the challenge of infertility so as to provide heirs for their husbands and their descendents. Kunti and Madri deal with a curse placed upon their husband Pandu by utilizing a mantra that allows them to call upon the gods of their choice to impregnate them. To ensure that her husband Dhrtarastra has progeny Gandhari manipulates the product of her conception so as to bring the births of one hundred sons and one daughter. The author skillfully extrapolates from these stories to show how they can be used to discuss ethical issues such as fertility medications, sperm banks, donor artificial insemination, in vitro fertilization, embryonic transfer and surrogacy. The third chapter uses the Mahabharata narrative as a source for ethical guidelines related to: 1) the priority placed on having children; 2) the acceptance of a variety of creative means to produce children; and 3) the active role women can take in controlling their reproductive choices. Bhattacharyya shows that these ancient Hindu stories produce intriguing and insightful approaches when related to contemporary discussions. To offer a comparative analysis these Hindu approaches are compared and contrasted with those of the Hebrew Bible, the New Testament, and especially Roman Catholic teachings. Chapter 4 offers a description of the key elements found within the Mahabharata and the Hindu worldview that provide a basis for Hindu bioethics. These include: 1) the centrality of society; 2) belief in the underlying unity of all life; 3) the responsibilities and flexibility of dharma; 4) the diversity within Hinduism; 5) the theory of karma; and, 6) the teachings of ahimsa.

The core of the book's contribution to knowledge comes in Chapter 5 titled an "Application of Hindu Thought." Bhattacharyya begins by correctly observing that previous writings on Hindu ethics (e.g. by Coward, Lipner, Young and Cromwell Crawford) have 
been very theoretical in nature. While she includes the theoretical writings of Hindu law texts, such as the Laws of Manu, and the philosophical ideas of Sankara, Bhattacharyya's original contribution is to offer analysis in applied Hindu ethics focused on Assisted Reproductive Technology. This she does by utilizing her own clinical experience as a nurse, interviews with a few California Hindu informants and by applying the six elements of Hindu thought (drawn from the Mahabharata) to a real life contemporary case study - the 1995 birth of Jaycee Buzzanca as a result of IVF from anonymous donors, surrogacy gestations and birth under legal contract from the parents who divorce before the baby is born. The strength of this case study is that it highlights many of the legal and ethical challenges associated with assisted reproductive technology. Its weakness is that as the couple involved were not Hindu, the application of Hindu ethics remains at the level of theoretical extrapolation. Nonetheless, the real life legal and ethical issues raised by the case study are given an interesting and informative reading when seen through the Hindu lens of the Mahabharata narratives of Kunti, Madri and Gandhari in their struggles with infertility. It is to be hoped that Swasti Bhattacharyya will not stop here, as she does in this book, but will look for a case study of a contemporary Hindu family to analyze. Her clear thinking and writing demonstrate that she has the required theoretical and clinical knowledge to carry out such a task effectively.

Other than this desire for a further Hindu case study, my only criticism is that the comparison with Christianity is flawed by limiting the analysis to Roman Catholicism. While Bhattacharyya is careful to repeatedly emphasize that the Hindu tradition is very diverse and composed of many Hinduisms, her presentation of Christianity as Roman Catholicism in its most rigid and dogmatic form ignores the reality that Christianity too is very diverse. As a Protestant I felt shortchanged by this approach which made Christianity into a Roman Catholic "straw-man" that compared very poorly with the greater flexibility of the Hindu approach. The author's laudable sensitivity to the diversity of Hindu traditions needs to be sharpened to see the large diversity that exists within Christian traditions. As scholars now say, there are many Christianities. But, this comparative quibble aside, Bhattacharyya has written a clear, concise contribution to the Hindu Ethics of Assisted Reproductive Technology. It should be required reading for doctors, nurses and health care workers dealing with Hindu families struggling with infertility. The writing and thinking is so clear and carefully conceived that the book will also be helpful to Hindu families dealing with the problem.

Harold Coward

University of Victoria

\section{Spiritual But Not Religious? An Oar Stroke Closer to the Farther Shore. Reid B. Locklin. Collegeville: The Liturgical Press, 2005, 152} pp.

REID Locklin's Spiritual but Not Religious? represents 1 an unusual constellation of circumstances. Locklin wrote the book within a four-month period upon finishing his Ph.D. dissertation on the theologies of Adi Shankaracharya and St. Augustine of Hippo. With Shankara and Augustine still swimming in his head, Locklin reflects on his conversion to Catholicism, ten years prior, an event that surprised him and many others he knew. The crux of this surprise and an ecclesiological/theological issue with which Locklin's book grapples has to do with the fact that his allegiance to Catholicism cannot be separated from his affiliation with an institution that is marred (in a particularly grand way) by imperfection. Spiritual but Not Religious? is Locklin's thoughtfully variegated. response to a turn of phrase likely familiar to those reading this review, used by those who prefer to claim a 